Journal of Tropical Resources and Sustainable Science

journal homepage: jtrss.org

\title{
Floristic composition, diversity and structure of Khaya senegalensis stands in Benue Department, Cameroon
}

\author{
Awé Djongmo Victor ${ }^{*}$, Noiha Noumi Valery ${ }^{1,2}$, Madou Chantal $^{3}$ and Zapfack Louis ${ }^{4}$ \\ ${ }^{1}$ Department of Biological Sciences, Faculty of Science, University of Ngaoundere, P.O.BOX: 454, Ngaoundere, Cameroon. \\ ${ }^{2}$ Higher Teacher Training College (ENS) of Bertoua, Department of Life Science, University of Ngaoundéré, P.O.Box 652 Bertoua, \\ Cameroon. \\ ${ }^{3}$ IRAD of Garoua, P.O.BOX:415, Garoua, Cameroon. \\ ${ }^{4}$ Department of Biology and Plant Physiology, Faculty of Science, University of Yaoundé I, P.O.Box: 812 Yaoundé, Cameroon
}

Received 6 September 2018

Accepted 16 January 2019

Online 30 June 2020

Keywords:

Cameroon; diversity; floristic composition; Khaya senegalensis; structure.

凶*Corresponding author: Awé Djongmo Victor

Department of Biological Sciences, University of Ngaoundere, Faculty of Science, PO Box: 454 ,

Ngaoundere, Cameroon.

Email: awevictor20@yahoo.fr

\begin{abstract}
The present work has been done to provide basic data for a better conservation and valorization of Khaya senegalensis stands in Sudano-Sahelian zone of Cameroon. A $100 \mathrm{~m}$ x $50 \mathrm{~m}$ transect method was undertaken to measure floristic diversity through the use of species richness, Shannon index, Pielou equitability, Simpson index, importance value index and importance value family. The vegetation structure is determined by density, basal area and biovolume. The inventory included trees with a dbh $\geq 10 \mathrm{~cm}$ on an area of 1 ha per plot. A total of 6743 individuals distributed in 24 families, 33 genera and 54 species were inventoried in all Khaya senegalensis stands studied. Statistical analysis showed significant differences, Shannon index, Simpson index, Pielou equitability, density, basal area, biovolume, species richness, heights class, diameters class, circumferences class but does not certify a significant difference of importance value index among in the villages. The undergrowth of Khaya senegalensis stands is more diverse at Bamé with a Shannon diversity index ( $\mathrm{ISH}=5.87 \pm 0.12 \mathrm{bit}$ ). The greatest of Pielou equitability is observed at Bamé $(\mathrm{EQ}=0.80 \pm 0.01)$. The largest of Simpson index is recorded at Bamé $(\mathrm{D}=0.098 \pm 0.001)$. Khaya senegalensis $\mathrm{Stands}$ are denser at Bamé $(194 \pm 3.12$ individuals $/ \mathrm{ha})$. The basal area and biovolume of Khaya senegalensis stands are very high at Bamé $(\mathrm{BA}=25.87 \pm$ $0.06 \mathrm{~m}^{2} / \mathrm{ha}$ and Biovolume $=15.32 \pm 0.012 \mathrm{~m}^{3} / \mathrm{ha}$ ). The species importance value is maximal in all the studied villages ( $\mathrm{SIV}=300 \pm 71.45$ ). The importance value index of species revealed a clear dominance in the undergrowth of Khaya senegalensis stands are Combretum adenogonium; Acacia senegal; Terminalia laxiflora; Guiera senegalensis; Acacia nilotica; Entada Africana. The vertical structure has three aspects, like the L (Dbh), asymmetric (height) and dissymmetrical (circumference) structures attesting to a strong regeneration of the understory ligneous woods of Khaya senegalensis stands studied.

(C) 2020 UMK Publisher. All rights reserved.
\end{abstract}

\section{1.}

\section{INTRODUCTION}

Over these two decades, Sub-Saharan Africa is facing an accelerated degradation of its plant biodiversity following anthropogenic and natural activities (Ndjidda, 2001). Living populations in these countries are highly dependent on natural plant resources and often have relatively limited adaptive capacity (IPCC, 2006). According to the IUCN 2007 classification, human factors related to resource use practices are one of the causes of the loss of biodiversity. In Cameroon, human pressure has caused a gradual degradation of natural resources in Sudan and Sahel. Conservation remains a major challenge. There is indeed a strong anthropic pressure and an excessive and uncontrolled use of the wood resource in the savannah ecosystems in Northern region, Cameroon; these are the causes weighing on biodiversity. These major impacts on natural environments lead to the destruction of species and their habitat, including threatened plant species.

Khaya senegalensis is a large tree of the multipurpose Meliaceae family, widespread in tropical dry Africa, which is used to control wind erosion, also used as fodder for livestock (Arbonnier, 2000, Gaoue \&Ticktin, 2007). Khaya senegalensis is a sacred tree for some tribes. Its wood is more often used in construction, cabinet making, and carpentry and also as firewood. All parts are used in traditional pharmacopoeia (Arbonnier, 2000). Leaves, flowers, roots and young twigs are popular as decoctions, cooking; powder (Arbonnier, 2000). Also used in medico-magic (specially to fight against madness) (Gaoue \& Ticktin, 2008). This species is importance of socio-economic and environmental. According to the 
IUCN Red List, Khaya senegalensis is listed in this list as a vulnerable species with special status (Gaoue \& Ticktin 2008). Overexploited, threatened by fire, overgrazing and drought, this species is in sharp decline (FAO, 2001). In Northern Cameroon, the big feet of Khaya senegalensis are rare in Sudanian savannahs. However, in the Sudanian zone, particularly in Cameroon, knowledge about the floristic composition, diversity and structure of Khaya senegalensis stands is very limited, if not unavailable. However, biodiversity provides a lot of information about the functioning, ecological and economic productivity of ecosystems. It would therefore be important to have sufficiently accurate information on the floristic structure of the undergrowth of Khaya senegalensis stands. Hence the interest of this work is to contribute to the improvement of knowledge for a sustainable safeguard of biodiversity while improving the incomes of local communities.

\subsection{Study area}

The study was conducted in North region, Benue Department, Cameroon. This region is located between latitude $9^{\circ} 18^{\prime}$ North and longitude $13^{\circ} \quad 23^{\prime}$ East (Abdoulay, 2012) (Fig.1). The terrain is a wide pediplain Between the Mandara Mountains (1442 m) in the North and the plateau of the Adamawa to the south. The climate is Sudano-sahelian type with two seasons: a dry season of duration of six months (November-May) and a rainy

\section{MATERIALS AND METHODS}

\subsection{Data sampling}

The experimental set-up consists of transects ranging from $100 \mathrm{~m}$ long to $50 \mathrm{~m}$ wide. These transects were arranged in a North-South direction to cover most or all of Khaya senegalensis stands in the six villages studied. The sampling tapes were established using the wires and the compass. At the ends of each strip, the milestones were marked equidistant $20 \mathrm{~m}$ from the base. At each distance of $20 \mathrm{~m}$, all the trees have been inventoried. Geographic coordinates were collected using GPS for each tree in the sample to determine its geographical location on the ground. All the trees were systematically counted and measured. Dendrometric data were based on dbh (Diameter of Breast hearth), height and trunk size. For example, the circumferences of the trees were measured with a tape measure at $1.3 \mathrm{~m}$ from the ground for tall trees and at $50 \mathrm{~cm}$ from the ground for shrubs and shrubs.

\subsection{Analysis of data}

The data has been encoded in the Excel software and then analyzed thanks to software Statgraphics plus 5.0. Duncan's test to 5\%.

\subsection{Floristic diversity}

-Species richness $(\mathrm{N})$ indicates the number of species responsible for the observed diversity. It is given by the formula: $\mathrm{N}=2^{\mathrm{H}} ; 2$ is the basis of the logarithm used to calculate the Shannon diversity index $(\mathrm{H})$. season of duration of six months (June-October) (Abdoulay, 2012). The mean monthly temperature evolving from $26^{\circ} \mathrm{C}$ in August to $40^{\circ} \mathrm{C}$ in March.

The soil is ferruginous type characterized by an acidity ( $\mathrm{pH}=5.5$ to 6 ), and a low cation exchange capacity (Noiha et al., 2017). The vegetation is a savannah shrub Sudanian zone having an aspect of clear savannah and degraded around the villages (Letouzey, 1985). Agriculture is the main activity of the populations in the North region. The population practice subsistence farming (corn; peanut and mil).

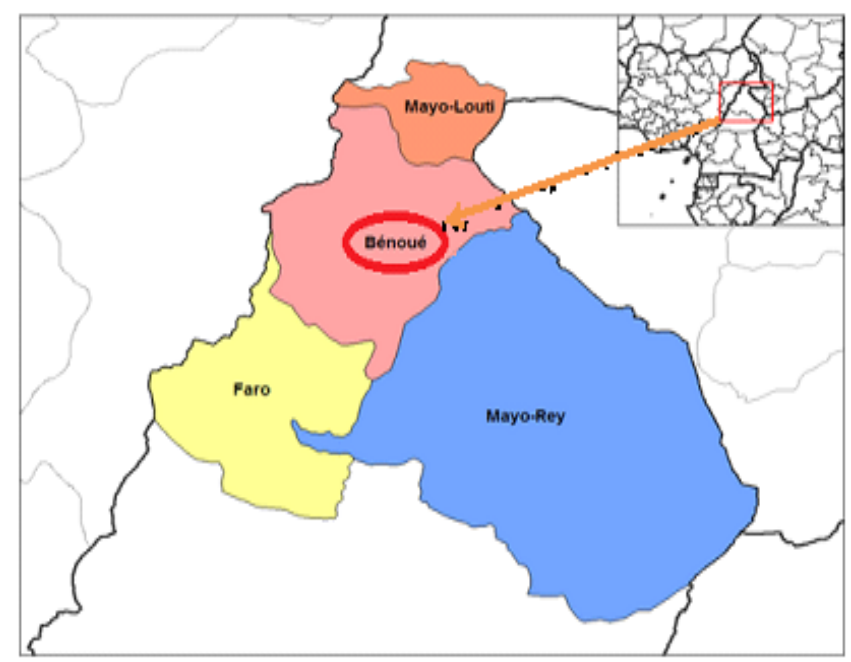

Figure 1: Map of study area location (Abdoulay, 2012).

-Shannon Diversity Index (ISH) (Frontier and Pichodviale, 1992): ISH $=-\Sigma(\mathrm{ni} / \mathrm{N}) * \log _{2}(\mathrm{ni} / \mathrm{N})$, with $\mathrm{ni}=$ number of species i, $\mathrm{N}=$ effective of all species; ISH is expressed in bit.

- Pielou equitability (EQ) (Pielou, 1969): EQ = ISH $/ \log _{2} \mathrm{~N}$.

- Simpson's index (Colinvaux, 1986): $\mathrm{D}=1-\sum(\mathrm{ni} / \mathrm{N})^{2}$ (Begon et al., 1998).

- Density (D): $D=n / S$; D: density (in trees/ha), n: number of trees present on the surface considered and $\mathrm{S}$ : basal area $\left(\mathrm{m}^{2} / \mathrm{ha}\right)$.

- Basal area of a tree corresponds to the area occupied by the tree trunk at the level of the dhp. It is given by the formula: Basal area $=\mathrm{dhp}^{2} \times 0.25 \times 9$ (Dawkins, 1959).

- Biovolume is defined as the volume of wood provided by vegetation in a given area. It makes it possible to estimate the wood potential of the plant formation. It is given by the formula of Dawkins. (1959): $\mathrm{V}=0.53$ ågi $\mathrm{x}$ hi $x$ ni with gi: basal area $\left(\mathrm{m}^{2} / \mathrm{ha}\right)$. Hi: height of the barrel (m); ni: number of individuals; $\mathrm{V}$ : biovolume $\left(\mathrm{m}^{3} / \mathrm{ha}\right)$. According to Roger and Rabarison (2000), biovolume is high when it is higher than $250 \mathrm{~m}^{3} /$ ha, average when it is between 50 and $250 \mathrm{~m}^{3} / \mathrm{ha}$, and low, when it is lower than $50 \mathrm{~m}^{3} /$ ha.

-Relative density $=$ (total basal area for one species $/$ total basal area of all species) $\times 100$. 
-Relative density $=$ (number of individuals of the species $/$ total number of individuals all species combined) $\times 100$.

Relative frequency $=$ (frequency of species $/$ sum of all frequencies of other species $) \times 100$.

-Relative diversity $=$ (number of species in the family / total number of species present $) \times 100$.

- Species Importance Value (SIV) (Curtis and Macintosh (1950)): SIV = Relative Dominance (Species) + Relative Density (Species) + Relative Frequency (Species).

- Family Importance Value (FIV) = relative dominance + relative density + relative diversity.

\subsection{Vertical structure}

The distribution of woody individuals in class of diameter, height and circumference was performed. For diameter class distribution and circumference, trees were distributed by diameter class and stem distribution histograms were constructed to characterize the diametric structure of the vegetation. 7 to 10 diameter classes with amplitude equal to $10 \mathrm{~cm}$ have been established. From the results of the height measurements, the individuals were grouped in class of amplitude $4 \mathrm{~cm}$ all these classes were then simplified in large classes: regeneration, rods of futures, medium stems and big trees.

\section{RESULT AND DISCUSSION}

\subsection{RESULT}

\subsubsection{Specific richness}

A total of 6743 individuals distributed in 24 families, 33 genera and 54 species were identified in all the stands of Khaya senegalensis studied in the six villages. Khaya senegalensis stands in Bamé village are richer in terms of phytodiversity (Table1).

Table 1: Species richness in each village studied.

\begin{tabular}{lllll}
\hline Villages & $\mathrm{Nf}$ & $\mathrm{Ng}$ & $\mathrm{Ns}$ & $\mathrm{Ni}$ \\
\hline & & & & \\
\hline Sanguéré-Paul & 11 & 12 & 23 & 1036 \\
Bame & 19 & 21 & 32 & 1564 \\
Sanguéré -Ngal & 11 & 13 & 21 & 1011 \\
Bockli & 10 & 12 & 30 & 1034 \\
Djalingo & 13 & 18 & 28 & 1512 \\
Mayo-Djarendji & 9 & 10 & 18 & 586 \\
\hline Total & 24 & 33 & 54 & 6743
\end{tabular}

Nf: Number of families, Ng: Number of genera, Ns: Number of species, Ni: Number of individuals

\subsubsection{Taxonomic abundance}

In sangéré-paul, the Combretaceae are more represented (32.73\%) (Fig.2A). in Bamé, the Caesalpiniaceae are more represented (45\%) (Fig.2B). In Sanguéré-Ngal, the Fabaceae are more represented (46.4 \%) (Fig.2C). In Bockli, found, the Anacardiaceae are more represented (81.56\%) (Fig.2D). In Djalingo, the Rubiaceae are more represented (31.52\%) (Fig.2E). In Mayo-Djarendji, the Loganiaceae are more represented (76.80 \%) (Fig.2F).

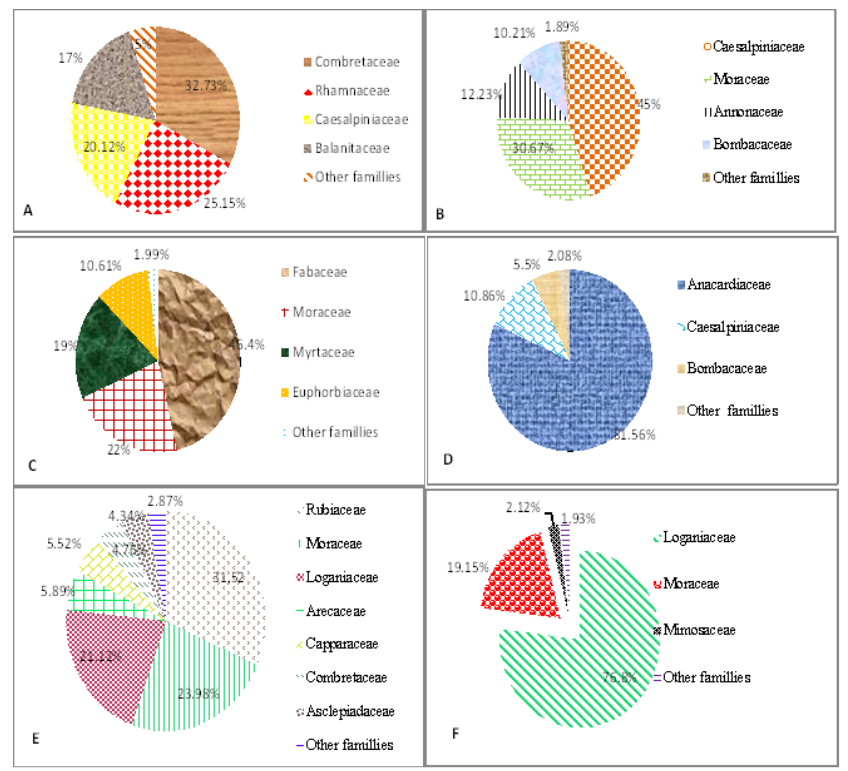

Figure 2: Taxonomic abundances of families in each studied village.

\subsubsection{Species importance value index}

Acacia sieberiana has the highest SIV in the Sanguéré-paul village with $178.60 \%$. On the other hand, in Bamé village, Tamarindus indica has the highest SIV with $183.21 \%$. Faidherbia albida has the highest SIV in Sanguéré-Ngal village with $146.86 \%$ Guiera senegalensis has the highest SIV in Bockli village with $70.39 \%$. Acacia nilotica has the highest SIV in Djalingo with $150.45 \%$. On the other hand, in Mayo-Djarendji village, Acacia polyacantha has the highest SIV with $100.55 \%$ (Table 2).

Table 2: Representations of the most important species in terms of ecological index.

\begin{tabular}{|c|c|c|c|c|c|}
\hline Villages & Espèces & $\begin{array}{l}\text { DoR } \\
\mathrm{e}\end{array}$ & $\begin{array}{l}\text { DeR } \\
\mathrm{e}\end{array}$ & $\mathrm{FeRe}$ & IVI \\
\hline \multirow{5}{*}{$\begin{array}{l}\text { Sanguér } \\
\text { é -Paul }\end{array}$} & Anacardium occidentale & 0.04 & 5.16 & 5.16 & 10.37 \\
\hline & Acacia sieberiana & $\begin{array}{l}80.4 \\
1\end{array}$ & $\begin{array}{l}49.0 \\
9\end{array}$ & $\begin{array}{l}49.0 \\
9\end{array}$ & $\begin{array}{l}178.6 \\
0\end{array}$ \\
\hline & Jatropha curcas & 4.51 & 2.84 & 2.84 & 10.19 \\
\hline & Balanites aegyptiaca & 2.93 & $\begin{array}{l}12.2 \\
4\end{array}$ & $\begin{array}{l}15.2 \\
4\end{array}$ & 30.42 \\
\hline & Ficus glomusa & 0.04 & 5.07 & 5.07 & 10.19 \\
\hline \multirow{4}{*}{ Bamé } & $\begin{array}{l}\text { Hexallobus } \\
\text { monopetalus }\end{array}$ & 0.13 & 7.73 & 8.73 & 16.61 \\
\hline & Tamarindus indica & $\begin{array}{l}97.1 \\
3\end{array}$ & $\begin{array}{l}45.5 \\
4\end{array}$ & $\begin{array}{l}40.5 \\
4\end{array}$ & $\begin{array}{l}183.2 \\
1\end{array}$ \\
\hline & Acacia senegal & 0.49 & $\begin{array}{l}13.8 \\
5\end{array}$ & $\begin{array}{l}13.8 \\
5\end{array}$ & 28.20 \\
\hline & Diospyros mespiliformis & 0.32 & 9.17 & 9.17 & 18.66 \\
\hline \multirow{5}{*}{$\begin{array}{l}\text { Sanguér } \\
\text { é -Ngal }\end{array}$} & Ximenia amaricana & 0.07 & 5.52 & 5.52 & 11.13 \\
\hline & Faidherbia albida & $\begin{array}{l}84.0 \\
2\end{array}$ & $\begin{array}{l}32.4 \\
1\end{array}$ & $\begin{array}{l}30.4 \\
1\end{array}$ & $\begin{array}{l}146.8 \\
6\end{array}$ \\
\hline & Terminalia laxiflora & 2.10 & $\begin{array}{l}14.1 \\
9\end{array}$ & $\begin{array}{l}14.1 \\
9\end{array}$ & 30.49 \\
\hline & $\begin{array}{l}\text { Terminalia } \\
\text { schimperiana }\end{array}$ & 1.25 & 6.87 & 8.85 & 16.98 \\
\hline & Piliostigma thonningii & $\begin{array}{l}78.7 \\
8\end{array}$ & $\begin{array}{l}10.8 \\
9\end{array}$ & $\begin{array}{l}12.8 \\
7\end{array}$ & $\begin{array}{l}104.5 \\
5\end{array}$ \\
\hline & Guiera senegalensis & 4.44 & $\begin{array}{l}30.4 \\
8\end{array}$ & $\begin{array}{l}35.4 \\
6\end{array}$ & 70.39 \\
\hline
\end{tabular}




\begin{tabular}{|c|c|c|c|c|c|}
\hline \multirow[t]{4}{*}{ Bockli } & Prosopis africana & 3.82 & 4.53 & 6.51 & 14.86 \\
\hline & Vitellaria paradoxa & 1.33 & 7.54 & 9.52 & 18.40 \\
\hline & Burkea africana & 1.41 & 5.62 & 5.60 & 12.63 \\
\hline & Vitex doniana & 0.33 & $\begin{array}{l}11.1 \\
1 \\
\end{array}$ & $\begin{array}{l}11.1 \\
1 \\
\end{array}$ & 22.56 \\
\hline \multirow{5}{*}{ Djalingo } & Gardenia aqualla & 0.07 & 5.52 & 5.52 & 11.13 \\
\hline & & 88.0 & 30.4 & 31.0 & 150.4 \\
\hline & Acacla nılotıca & 2 & 1 & 2 & 5 \\
\hline & Sclerocari abirrea & 2 & $\begin{array}{l}14.1 \\
9\end{array}$ & 14.1 & 30.39 \\
\hline & Strychnos spinosa & 1.25 & 6.87 & 8.85 & 16.98 \\
\hline \multirow{6}{*}{$\begin{array}{l}\text { Mayo- } \\
\text { Djarendj } \\
\mathrm{i}\end{array}$} & Acacia polvacantha & 72.7 & 10.8 & 10.8 & 100.5 \\
\hline & & 8 & 9 & 7 & 5 \\
\hline & Detarium microcarpum & 0.44 & 33.4 & 30.4 & 64.39 \\
\hline & Sclerocaria birrea & 3,82 & 4.53 & $\begin{array}{l}0 \\
4.51\end{array}$ & 12.86 \\
\hline & Boswellia papyrifera & 1.33 & 7.54 & 9.52 & 18.40 \\
\hline & $\begin{array}{l}\text { Commiphora } \\
\text { pedunculata }\end{array}$ & 0.41 & 5.62 & 7.60 & 11.63 \\
\hline
\end{tabular}

Relative dominance (DoRe), relative density (DeRe), relative frequency (FeRe), Species importance value (SIV).

\subsubsection{Family importance value index}

The most representative families in the undergrowth of Khaya sengalensis stands with a high FIV value are Sapotaceae in Sanguéré-Paul village (IVF = 40.19); Meliaceae in Bamé village (FIV $=98.21$ ); Fabaceae in Sanguéré-Ngal village (FIV $=146.86$ ); Caesalpiniaceae in Bockli village ( $F I V=118.40)$; Verbenaceae and Asclepiadaceae in Djalingo village with respectively (FIV $=150.45$ and 111.55); Moraceae in Mayo-Djarendji village $(\mathrm{FIV}=150)($ Table 3$)$.

Table 3: Representations of the most important families in terms of ecological index.

\begin{tabular}{lll|ll}
\hline Villages & Familles & FIV & Familles & FIV \\
& Meliaceae & 10.37 & Myrtaceae & 20.37 \\
Sanguéré & - Anacardiaceae & 12.60 & Rubiaceae & 138 \\
Paul & Annonaceae & 8 & Sapotaceae & 40.19 \\
& Asclepiadaceae & 20.11 & Scleropiadaceae & 29.42 \\
& Bombacaceae & 10.19 & Other families & 6.75 \\
\hline \multirow{5}{*}{ Bamé } & Burseraceae & 16.61 & Loganiaceae & 16.61 \\
& Caesalpiniaceae & 33.21 & Meliaceae & 98.21 \\
& Capparaceae & 30.28 & Verbenaceae & 48.20 \\
& Celastraceae & 18.66 & Mimosaceae & 18.66 \\
& Combretaceae & 11.43 & Other families & 9.13 \\
\multirow{5}{*}{ Sanguéré } & Fabaceae & 146.86 & Arecaceae & 4.86 \\
Ngal & Sterculiaceae & 30.49 & Apocynaceae & 4.49 \\
& Eunnaraceae & 16.98 & Malvaceae & 6.98 \\
& Euphorbiaceae & 13.01 & Moringaceae & 4.55 \\
& Bignoniaceae & 70.39 & Other families & 1.39 \\
\hline \multirow{3}{*}{ Bockli } & Rhamnaceae & 15 & Myrtaceae & 98.01 \\
& Caesalpiniaceae & 118.40 & Meliaceae & 18.40 \\
& Sapotaceae & 12.44 & Anacardiaceae & 12.63
\end{tabular}

\begin{tabular}{lll|ll} 
& Mimosaceae & 22.56 & Other families & 2.56 \\
\hline \multirow{3}{*}{ Djalingo } & Meliaceae & 11.61 & Asclepiadaceae & 111.55 \\
& Verbenaceae & 150.45 & Bombacaceae & 23.45 \\
& Mimosaceae & 50.55 & Other families & 3.39 \\
\hline \multirow{5}{*}{ Mayo- } & Sapotaceae & 25 & Sterculiaceae & 30.98 \\
Djarendji & Moraceae & 150 & Connaraceae & 30 \\
& Scleropiadaceae & 19.02 & Balanitaceae & 9.40 \\
& Fabaceae & 11 & Bignoniaceae & 5.44 \\
\hline
\end{tabular}

\subsubsection{Analysis of diversity indices and similarities between sites}

Analysis of variance reveals that there are significant differences $(p<0.05)$ for species richness of trees with a higher value in Bamé village $(52 \pm 0.11)$ (Table 4). The Shannon diversity index in Bamé village (5.87 \pm 0.12 bits) shows the greatest diversity in this site. This Shannon index varies significantly $(\mathrm{p}<0.05)$ between stands (Table 4).

Analysis of variance reveals that there are significant differences $(p<0.05)$ in this Pielou equitability between the sampled stands. The Pielou equitability is maximal in Bamé village $(0.80 \pm 0.01)$ (Table 4). The average circumference of the individuals is important in Bamé Village stands $(68 \pm 0.11 \mathrm{~cm})$. Variance analysis reveals that there are significant differences $(p<0.05)$ in the average circumferences of individuals between sampled stands (Table 4). Simpson's index is higher in Bamé village $(0.098 \pm 0.001)$ and varies significantly $(p<0.05)$ between sites (Table 4).

For the mean DBH, the analysis shows that there is a significant difference $(p<0.05)$ between sites with a higher value in Bamé village (54.12 \pm 0.21$)$ (Table 4). Considering the sites, there are very significant differences $(p<0.05)$ for the density. The highest average tree trunk density is recorded in Bamé village (194 \pm 3.12 individuals/ha) (Table 4). For mean basal area, the analysis shows that there is a significant difference ( $p$ $<0.05$ ) between sites with a higher value in Bamé village $\left(25.87 \pm 0.06 \mathrm{~m}^{2} / \mathrm{ha}\right)$ (Table 1).

Statistical analysis shows a significant difference to biovolume between sites $(\mathrm{P}<0.05)$. The highest average biovolume was recorded in Bamé village (15.32 $\pm 0.012 \mathrm{~m} 3 / \mathrm{ha}$ ) (Table 4). Statistical analysis does not indicate a significant difference importance value index between villages $(\mathrm{P}>0.05)$. It is worth $(\mathrm{IVI}=300 \pm 71.45)$ in all villages (Table 4). 
Table 4: Floristic diversity and structural characterization.

\begin{tabular}{|c|c|c|c|c|c|c|}
\hline Diversity parameter & Sanguéré -Paul & Bamé & Sanguéré -Ngal & Bockli & Djalingo & Mayo-Djarendji \\
\hline Specific richness (Rs) & $23 \pm 0.02^{\mathrm{b}}$ & $52 \pm 0.11^{\mathrm{c}}$ & $21 \pm 0.01^{\mathrm{a}}$ & $30 \pm 0.10^{\mathrm{d}}$ & $28 \pm 0.03^{\mathrm{f}}$ & $18 \pm 0.011^{\mathrm{e}}$ \\
\hline Shannon index (ISH) & $2.98 \pm 0.01^{\mathrm{b}}$ & $5.87 \pm 0.12^{\mathrm{c}}$ & $2.15 \pm 0.02^{\mathrm{a}}$ & $3.54 \pm 0.02^{\mathrm{d}}$ & $3.07 \pm 0.03^{\mathrm{f}}$ & $1.87 \pm 0.00^{\mathrm{e}}$ \\
\hline Pielou's equitability (EQ) & $0.42 \pm 0.01^{\mathrm{a}}$ & $0.80 \pm 0.01^{\mathrm{b}}$ & $0.31 \pm 0.01^{\mathrm{c}}$ & $0.51 \pm 0.01^{\mathrm{d}}$ & $0.45 \pm 0.01^{\mathrm{a}}$ & $0.30 \pm 0.01^{\mathrm{c}}$ \\
\hline Simpson index (DS) & $0.061 \pm 0.00^{\mathrm{b}}$ & $0.098 \pm 0.001^{\mathrm{c}}$ & $0.045 \pm 0.003^{\mathrm{a}}$ & $0.084 \pm 0.004^{\mathrm{d}}$ & $0.078 \pm 0.006^{\mathrm{f}}$ & $0.038 \pm 0.00^{\mathrm{e}}$ \\
\hline Average diameter $(\mathrm{cm})$ & $11.67 \pm 0.03^{\mathrm{b}}$ & $54.12 \pm 0.21^{\mathrm{c}}$ & $34.56 \pm 0.05^{\mathrm{a}}$ & $28.12 \pm 0.12^{\mathrm{d}}$ & $21.76 \pm 0.01^{\mathrm{f}}$ & $26.76 \pm 0.05^{\mathrm{e}}$ \\
\hline Average circumferences $(\mathrm{cm})$ & $31 \pm 0.08^{\mathrm{b}}$ & $68 \pm 0.11^{\mathrm{c}}$ & $28 \pm 0.15^{\mathrm{a}}$ & $56 \pm 0.83^{\mathrm{d}}$ & $49 \pm 0.31^{\mathrm{f}}$ & $20 \pm 0.01^{\mathrm{e}}$ \\
\hline Density (tiges/ha) & $126 \pm 2.89^{\mathrm{b}}$ & $194 \pm 3.12^{\mathrm{c}}$ & $110 \pm 1.76^{\mathrm{a}}$ & $174 \pm 1.01^{\mathrm{d}}$ & $143 \pm 4.01^{\mathrm{f}}$ & $98 \pm 0.09^{\mathrm{e}}$ \\
\hline Basal area $\left(\mathrm{m}^{2} / \mathrm{ha}\right)$ & $16.94 \pm 0.03^{\mathrm{b}}$ & $25.87 \pm 0.06^{\mathrm{c}}$ & $12.56 \pm 0.01^{\mathrm{a}}$ & $18.01 \pm 0.02^{\mathrm{d}}$ & $14.23 \pm 0.01^{\mathrm{f}}$ & $9.23 \pm 0.00^{\mathrm{e}}$ \\
\hline Biovolume $\left(\mathrm{m}^{2} / \mathrm{ha}\right)$ & $6.45 \pm 0.01 \mathrm{~b}$ & $15.32 \pm 0.012 \mathrm{c}$ & $2.06 \pm 0.001 \mathrm{a}$ & $8.01 \pm 0.013 \mathrm{~d}$ & $3.96 \pm 0.011 \mathrm{f}$ & $1.29 \pm 0.001 \mathrm{e}$ \\
\hline Importance valeur index (IVI) & $300 \pm 71.45^{\mathrm{a}}$ & $300 \pm 71.45^{\mathrm{a}}$ & $300 \pm 71.45^{\mathrm{a}}$ & $300 \pm 71.45^{\mathrm{a}}$ & $300 \pm 71.45^{\mathrm{a}}$ & $300 \pm 71.45^{\mathrm{a}}$ \\
\hline
\end{tabular}

The assigned values of the same letter are not statistically different ( $p>0.05$, Duncan's test).

In terms of density, the most represented species in the undergrowth of Khaya senegalensis stands are Combretum adenogonium (80 \pm 6.98 individuals/ha) in Sanguéré-Paul village; Acacia senegal (49 \pm 0.43 individuals/ha) in Bamé village; Terminalia laxiflora (98 \pm 5.09 individuals/ha) in Sanguéré-Ngal village; Guiera senegalensis (44 \pm 1.98 individuals/ha) in Bockli village; Acacia nilotica ( $88 \pm 3.32$ individuals/ha) in Djalingo village; Entada africana $(82 \pm 2.65$ individuals/ha) in Mayo-Djarendji village (Table 5).

In terms of basal area, the most represented species in the undergrowth of Khaya senegalensis stands are Ficus glomusa $\left(15.67 \pm 1.02 \mathrm{~m}^{2} / \mathrm{ha}\right)$ in Sanguéré-Paul village; Tamarindus indica $\left(9.19 \pm 1.11 \mathrm{~m}^{2} / \mathrm{ha}\right)$ in Bamé village; Faidherbia albida (6.27 $\left.\pm 0.87 \mathrm{~m}^{2} / \mathrm{ha}\right)$ in Sanguéré-Ngal village; Vitellaria paradoxa $(8.21 \pm 0.05$ $\left.\mathrm{m}^{2} / \mathrm{ha}\right)$ in Bockli village; Sclerocaria birrea $(9.39 \pm 0.04$ $\left.\mathrm{m}^{2} / \mathrm{ha}\right)$ in Djalingo village; Boswellia papyrifera $(7.34 \pm$ $0.23 \mathrm{~m}^{2} / \mathrm{ha}$ ) in Mayo-Djarendji village (Table5).

Table 5: Density and basal area of the most represented species in the undergrowth of Khaya senegalensis stands at each site.

\begin{tabular}{|c|c|c|c|}
\hline Villages & Species & $\mathrm{D}$ & $\mathrm{BA}$ \\
\hline \multirow{5}{*}{$\begin{array}{l}\text { Sanguéré } \\
\text {-Paul }\end{array}$} & Anacardium occidentale & $14 \pm 0.98$ & $10.76 \pm 0.12$ \\
\hline & Combretum adenogonium & $80 \pm 6.98$ & $4.09 \pm 0.72$ \\
\hline & Jatropha curcas & $14 \pm 0.54$ & $2.09 \pm 0.03$ \\
\hline & Balanites aegyptiaca & $19 \pm 0.79$ & $2.44 \pm 0.02$ \\
\hline & Ficus glomusa & $10 \pm 0.01$ & $15.67 \pm 1.02$ \\
\hline \multirow{4}{*}{ Bamé } & Hexallobus monopetalus & $13 \pm 1.13$ & $7.33 \pm 0.17$ \\
\hline & Tamarindus indica & $39 \pm 0.23$ & $9.19 \pm 1.11$ \\
\hline & Acacia senegal & $49 \pm 0.43$ & $3.05 \pm 0.09$ \\
\hline & Diospyros mespiliformis & $32 \pm 0.65$ & $5.43 \pm 0.32$ \\
\hline \multirow{5}{*}{$\begin{array}{l}\text { Sanguéré } \\
\text {-Ngal }\end{array}$} & Ximenia amaricana & $27 \pm 1.33$ & $5.22 \pm 0.21$ \\
\hline & Faidherbia albida & $24 \pm 1.02$ & $6.27 \pm 0.87$ \\
\hline & Terminalia laxiflora & $98 \pm 5.09$ & $4.12 \pm 0.01$ \\
\hline & Terminalia schimperiana & $75 \pm 3.06$ & $5.01 \pm 0.04$ \\
\hline & Piliostigma thonningii & $48 \pm 1.54$ & $1.09 \pm 0.00$ \\
\hline \multirow{5}{*}{ Bockli } & Guiera senegalensis & $44 \pm 1.98$ & $7.14 \pm 0.02$ \\
\hline & Prosopis africana & $32 \pm 0.88$ & $4.59 \pm 0.07$ \\
\hline & Vitellaria paradoxa & $13 \pm 0.02$ & $8.21 \pm 0.05$ \\
\hline & Burkea africana & $11 \pm 0.23$ & $5.12 \pm 0.01$ \\
\hline & Vitexdoniana & $33 \pm 1.65$ & $1.91 \pm 0.00$ \\
\hline \multirow{5}{*}{ Djalingo } & Gardenia aqualla & $47 \pm 1.87$ & $5.02 \pm 0.021$ \\
\hline & Acacia nilotica & $88 \pm 3.32$ & $3.01 \pm 0.00$ \\
\hline & Sclerocaria birrea & $42 \pm 2.87$ & $9.39 \pm 0.04$ \\
\hline & Strychnos spinosa & $25 \pm 1.76$ & $6.07 \pm 0.54$ \\
\hline & $\begin{array}{l}\text { Acacia polyacantha } \\
\text { Detarium microcarp }\end{array}$ & $\begin{array}{l}78 \pm 1.43 \\
44 \pm 0.76\end{array}$ & $3.09 \pm 0.02$ \\
\hline
\end{tabular}

\begin{tabular}{llll} 
Mayo- & Entada africana & $82 \pm 2.65$ & $4.93 \pm 0.12$ \\
Djarendji & Boswellia papyrifera & $13 \pm 1.09$ & $7.34 \pm 0.23$ \\
& Commiphora pedunculata & $41 \pm 3.54$ & $5.67 \pm 0.04$ \\
\hline
\end{tabular}

D: Density individuals/ha), BA: Basal area $\mathrm{m}^{2} / \mathrm{ha}$ ).

\subsubsection{Floristic similarity}

The indices of similarity are generally very high and do not reflect a significant difference between the different stands of khaya senegalensis studied. However, these three plots sampled are more floristically similar, since they have floristic affinities greater than or equal to $60 \%$, thus forming the same plant community (Table 6).

Table 6: Floristic similarity.

\begin{tabular}{lccccc}
\hline Villages & A & B & C & D & E \\
\hline A & ----- & ---- & ---- & ---- & ---- \\
B & 73 & ---- & ---- & ---- & ---- \\
C & 88 & 86 & ----- & ----- & ---- \\
D & 61 & 66 & 74 & ---- & ----- \\
E & 76 & 87 & 62 & 75 & ---- \\
F & 69 & 83 & 85 & 92 & 94 \\
\hline
\end{tabular}

A: Sanguéré -Paul; B: Bamé;C: Sanguéré -Ngal;D : Bockli;E : Djalingo ;F : Mayo-Djarendji.

\subsubsection{Vegetation structure}

The figure 3 shows the diameter class distribution showing that the number of individuals per diameter class decreases with increasing diameter. This distribution has a decreasing exponential shape (L) with a strong slope of equation: $\mathrm{y}=141.11 \mathrm{e}^{-1.876 \mathrm{x}}$ and $\mathrm{R}^{2}=$ 0.7531, showing that the studied stands have several individuals of future to ensure the regeneration.

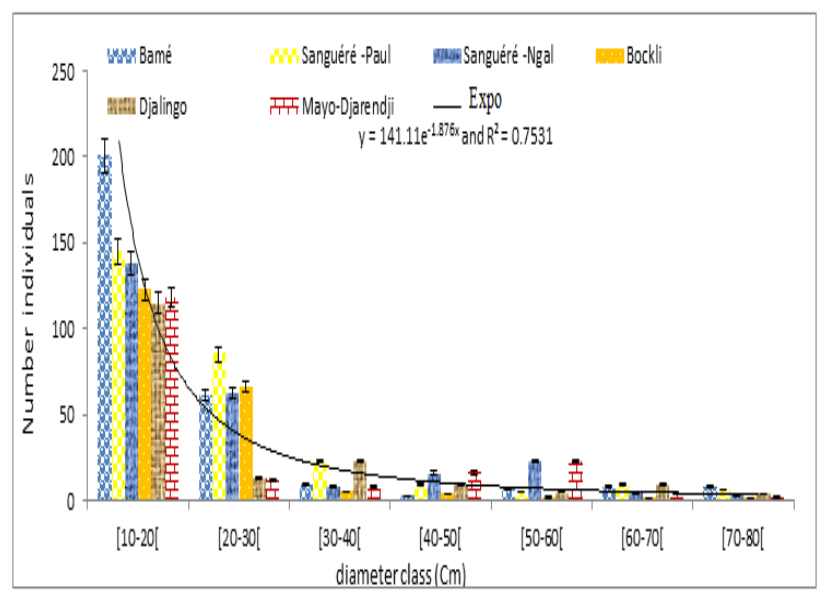

Figure 3: Diameter distribution by individuals in Village. 
Regarding the distribution of circumferences, the analysis shows that there is a highly significant difference $(p<0.05)$. At the village level, the highest circumferences classes are observed in Sanguéré-Ngal village. Its distribution in circumference class has the appearance of a curve in dissymmetrical close with a predominance of the class $70-80 \mathrm{~cm}$ in number of stems. This distribution fits better with a polygonal function whose equation is: $y=0.0355 x^{4}-1.2587 x^{3}+12.339 x^{2}-$ $35.731 \mathrm{x}+36$ and $\mathrm{R}^{2}=0.8386$ (Fig. 4 ).

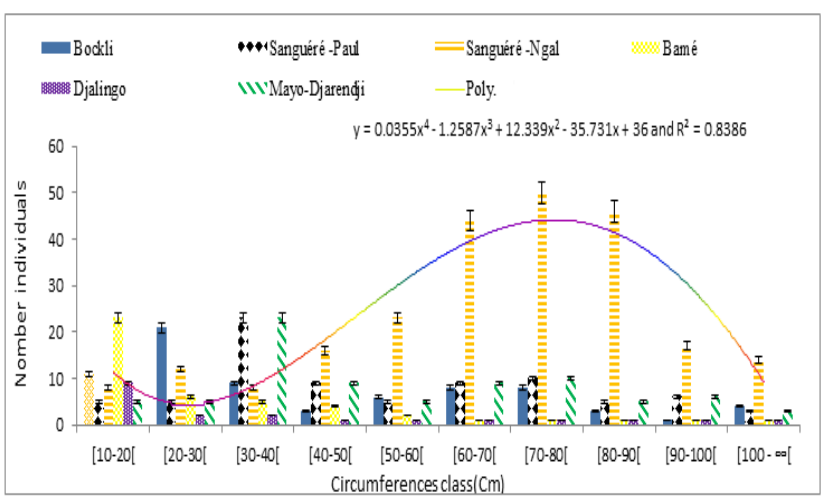

Figure 4: Circumferences distribution by individuals in Village.

For the height classes, the analysis shows that there is a highly significant difference $(p<0.05)$ at the village level, the highest height classes are observed in Sanguéré-Paul village. Indeed, Figure 5 shows the height class distribution has an asymmetrical bell structure centered on the diameter class 24 to $30 \mathrm{~cm}$ thus reflecting a predominance of individuals of average heights. This distribution fits better with a polygonal function whose equation: $y=-0.26 x^{5}+3.8397 x^{4}-18.795 x^{3}+31.796 x^{2}-$ $5.3189 \mathrm{x}+0.3$ and $\mathrm{R}^{2}=0.9578$, reflecting a good dynamic population, but with a greater number of stems in Sanguéré-Paul village than in other stands in the villages studied.

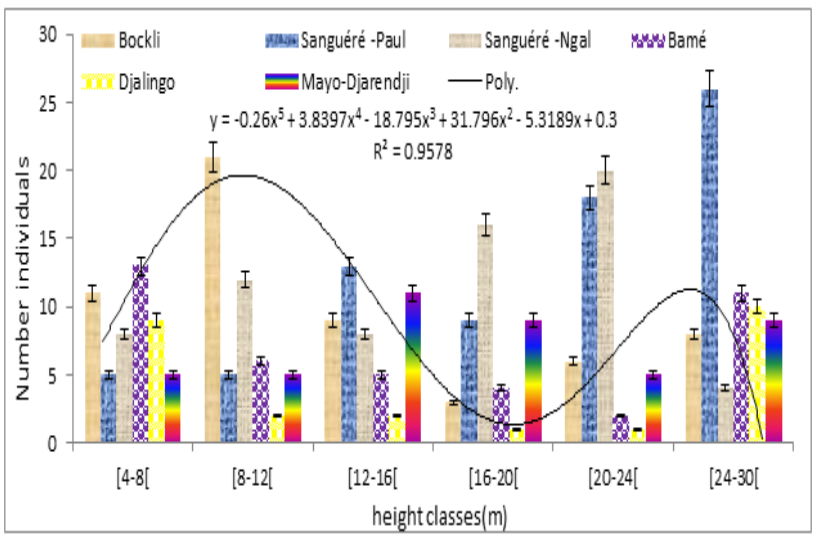

Figure 5: Height distribution by Individuals in Villages.

3.1.5. Annual cropping associated with the undergrowth of different Khaya senegalensis stands
For the annual undergrowth associations of Khaya senegalensis stands studied in the six villages, seven species are the most cultivated. In all localities, Mil is grown in $24 \pm 0.01 \%$ of plots in which there are annual crop associations. Cowpea $(13 \pm 0.04 \%)$, groundnuts $(12$ $\pm \%)$ are ranked third after maize, which is present in 21.5 $\pm 0.02 \%$ of plots in which there are annual crop associations. For cotton, sesame and Hibiscus sp are also cultivated but in small quantities with respectively $9.5 \pm$ $0.012 \%, 10 \pm 0.026 \%, 10 \pm 0.026 \%$ of plots in which there are annual crop combinations (Fig. 6).

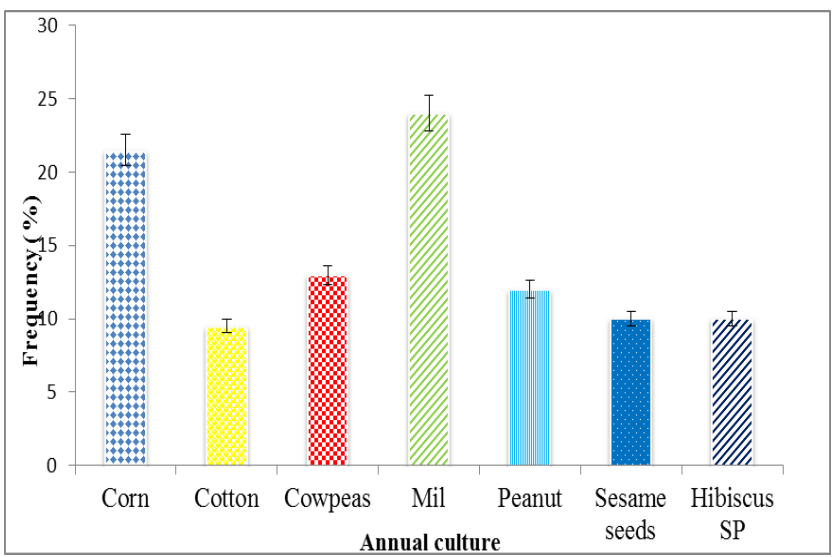

Figure 6: Proportion of annual crops associated in Khaya senegalensis stand studied.

Figures 7 and 8 shows the evolution of species richness, the Shannon index and Pielou's equitability according to the anthropization and aridity gradients. We have in the abscissa the groupings and in the ordinate the indices. He observes that the Shannon index is not correlated with the aridity gradient. We also note that the specific wealth does not always follow the Shannon index and Piélou's equitability. On the other hand, anthropization seems to affect species richness, the Shannon index and Piélou's equitability, since there is a slight increase in these three parameters with the accentuation of anthropization. These figures show that the specific diversity varies in a random way between the groups classified according to the two gradients.

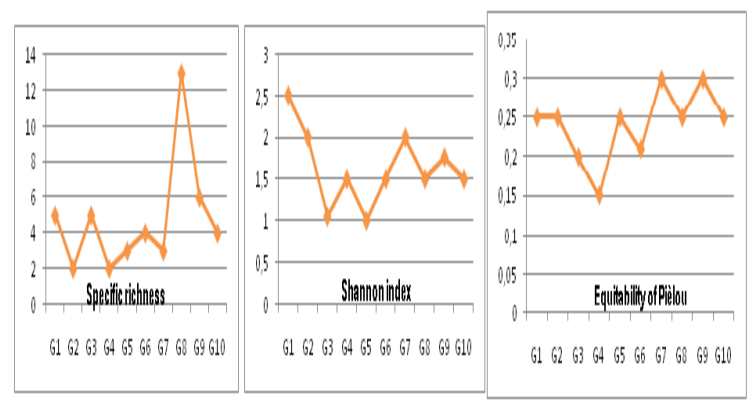

Figure 7: Phytodiversity according to the anthropization gradient 


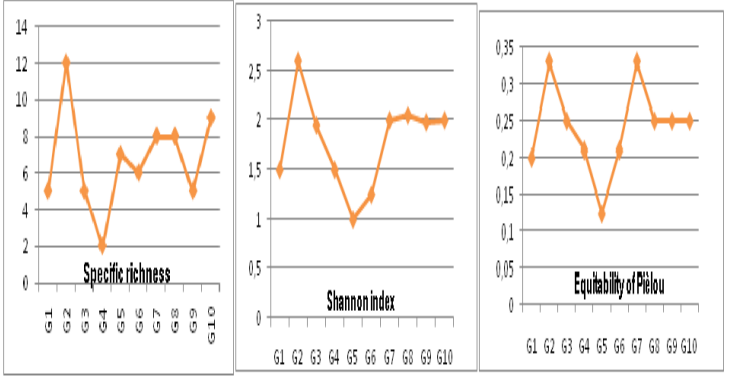

Figure 8: Phytodiversity according to the aridity gradient.

\subsection{DISCUSSION}

The floristic inventory identified a total of 6743 individuals ( $\mathrm{dbh} \geq 10 \mathrm{~cm}$ ) distributed in 24 families, 33 genera and 54 species. This shows that the undergrowth of Khaya senegalensis stands is very diverse with a predominance are Combretaceae, Caesalpiniaceae, Fabaceae, Anacardiaceae, Rubiaceae, Loganiaceae because the species in these families provide important social and economic services for the local population (Thiombiano et al., 2006, Avakoudjo et al., 2013, Savadogo et al., 2016). These are species whose products are used either in food or feed, as firewood or in construction. The dominance of these families could be explained by the fact that most species of these families are better suited to climatic conditions and human activities in Sudano-Sahelian zone.

The high species richness of Khaya senegalensis stands observed in Bamé village is explained by environmental conditions that would favor the regeneration of the most predominant species in the undergrowth of Khaya senegalensis stands as Acacia sieberiana; Tamarindus indica, Faidherbia albida; Guiera senegalensis; Acacia nilotica; Acacia polyacantha. In all the stands studied, thorny species are dominant because they are more adapted to water stress. This corroborates those of Laminou et al. (2009) in the Sahelian zone of Burkina-Faso.

A Khaya senegalensis stand has the highest value in Bamé village $(5.87 \pm 0.12$ bits $)$. This can be explained by the ecological conditions that would be favorable for the regeneration of the species present in the sites studied and also by the well-controlled anthropogenic actions cited by Noiha et al. (2018). This result is close to those Dongmo (2002) in the Young fallows, fallow averages, Old fallow, secondary forests, Cocoa forest zone of Cameroon with respectively 5.37 bits; 5.31 bits; 5.76 bits; 5.89 bits; 5.79 bits.

The pielou's equitability is maximum in Bamé village stands $(0.80 \pm 0.01)$. This high value reflects a good recovery of the floristic diversity of the undergrowth, probably because of the favorable conditions of the environment. Indeed, the Shannon indices and Pielou equitability vary significantly. The
Simpson index of Khaya senegalensis stands is very high in Bamé village $(0.098 \pm 0.001)$, this site has a heterogeneous distribution of their flora and the probability that two individuals is taken at random belonging to the same species is strong in this site.

The highest average densities in the stands were recorded in Bamé village (194 \pm 3.12 individuals/ha) which would represent an appreciable regeneration within the stands. In fact, the importance of regeneration in the stands studied is that it favors the protection of the land by preventing rainwater from having a beating effect thanks to foliage and root systems (Malagnoux et al., 2007). This result is in the range 103 to 267 individuals/ha obtained by Ali et al. (2014) in the sacred forests of south-eastern Benin. The most common species in the undergrowth of Khaya senegalensis stands are Combretum adenogonium; Acacia senegal; Terminalia laxiflora; Guiera senegalensis; Acacia nilotica; Entada africana.

The higher basal area observed in Bamé village $\left(25.87 \pm 0.06 \mathrm{~m}^{2} / \mathrm{ha}\right)$ is indicative of large tree specimens. Among the undergrowth species of Khaya senegalensis stands, some have a high shade rate, such as Ficus glomusa; Tamarindus indica; Faidherbia albida; Vitellaria paradoxa; Sclerocaria birrea; Boswellia papyrifera. This may explain the high proportion of species that can provide shade in any season (Leblanc \&Malaisse, 1978).

The importance value index does not vary and is very high in the sites (IVI $=300 \pm 71.45)$. This could be explained by the strong presence of tall-topped trees in the different stands studied. This finding is consistent with (Ngomet al., 2013; Noiha et al., 2018b), which asserts that crown trees contribute more to recovery and to a degree of recovery, altering ecological conditions. By reducing the evaporative power of the air, by promoting the water balance of the soil and by improving the fertility.

The floristic similarity in Khaya senegalensis stands in the six villages is greater than or equal to $60 \%$, due to the fact that the stands studied in the different villages are located in the same agro-ecological zone. This very high similarity means that there is little floristic difference between of Khaya senegalensis stands studied in the six villages of the Benue department.

According to local communities, the annual crops associated with the undergrowth of different in Khaya senegalensis stands give interesting yields and generate significant income. This situation is explained by the fact that the forest stands thus formed have a soil cover rate that favors the productivity of annual and sunloving crops. This mode of management of forest stands allows the diversification of the sources of income over time, which gives the capacity to the local communities to face the challenges of their economic development and 
the protection of their environment. The management of this diversity of groups of plants found in the undergrowth of the different in Khaya senegalensis stands studied, allows farmers to feed, treat, warm, beautify their surroundings and care for their environment at the same time (Mapongmetsem et al., 2009; 2016).

The analysis of the distribution of individuals by diameter classes reveals an "L" distribution with an exponential equation reflecting the predominance of small diameter individuals. This distribution has also been described by several authors in other ecosystems (Fongnzossie et al., 2008; Noiha et al., 2018). This distribution indicates that these ecosystems have a regular dynamic denoting a constant regeneration over time (Rasatatsihoarana, 2007; Noiha et al., 2018a) and characterizes a woody population that interacts with each other (Fongnzossie et al., 2008; Noiha et al., 2018c). The predominance of young plants would strongly influence tree diameter (Noihaet al., 2018b).

The height class distribution has an asymmetrical bell structure centered on the diameter class 24 to $30 \mathrm{~cm}$, thus reflecting a predominance of medium height individuals. This situation is observed in an unstable population characterized by an absence or a very small proportion of individuals in one or more classes (Ouédraogo, 2006; Noiha et al., 2018). It may be one of the consequences of recurring droughts due to the effects of strong pressure on fodder resources (Cornet et al., 2002; Lhoste, 2007 in Noiha et al., 2018).

This Ascending Hierarchical Classification (CAH) shows 10 groups of species according to the similarity of their diversity with formation of 5 complexes with the following similarities: (G2-G9): 40\% (G3-G8): 83\%; (G1-G7): 85\%; (G4-G10): 90\%; (G5-G6): 92\% dependent on their potential for diversity in SudanoSahelian zone of Cameroon. Diversity potential is the main determinant of the groups, with a clear separation between species with high density values of other species at low densities.

Gradients of anthropization and aridity generally affect woody diversity. These translate how anthropogenic pressures and climatic factors impacted in Khaya senegalensis stands and other stands in SudanoSahelian zone of Cameroon.

\section{CONCLUSION}

The present study made it possible to make an evaluation floristic diversity of Khaya senegalensis stands in Benue department, Northern region, Cameroon. This diversity is relatively high compared to other agroecological zones of Cameroon. Preponderance of woody species such as Acacia sieberiana; Tamarindus indica: Faidherbia albida; Guiera senegalensis; Acacia nilotica; Acacia polyacantha testifies to their resistance to sometimes difficult climatic conditions and to anthropic actions. All these data are arguments for the preservation and conservation of Khaya senegalensis stands. They also describe elements of biodiversity and provide information on the implementation of management guidelines for the safeguarding of such a plant species with multiple uses.

\section{ACKNOWLEDGMENTS}

We thank all the referred whose contributions have been very important for the improvement of this manuscript.

\section{REFERENCES}

Abdoulay M. (2012). Migrations, dynamiques agricoles et problèmes fonciers en Afrique subsaharienne ,10p.

Ali M. F. K. R, Odjoubere J., Tente H. A. B., Sinsin A. B. (2014). Caractérisation floristique et analyse des formes de pression sur les forêts sacrées ou communautaires de la Basse Vallée de l'Ouémé au Sud-Est du Bénin. Afrique Science, 10(2) :243-257.

Arbonnier M. (2000). Arbres, arbustes et lianes des zones sèches d'Afrique de l'Ouest. La librerie du CIRAD, ISBN Cirad, 2-87614431-X. 549Pp.

Avakoudjo J., Kindomihou V., Akponikpe P.I., Thiombiano A., Sinsin B. (2013). Essences végétales et techniques de restauration des zones d'érosion (dongas) du Parc W et de sa périphérie à Karimama (Nord-Bénin). Journal of Applied Biosciences, 69:54965509. ISSN, 1997-5902.

Colinvaux, P. (1986). Ecology. John Wiley \& Sons Inc., New York.

Cornet A, Lhoste P, Toutain B. (2002). Évaluation et durée des actions de lutte contre la désertification. Impacts environnementaux, sociaux et économiques. In Lutte contre la désertification dans les projets de développement : un regard scientifique sur l'expérience de l'AFD en Afrique sub-saharienne et au Maghreb. CSFD/AFD: Paris; $139-15$.

Curtis, J. T and McIntosh, R.P. (1950). The interrelations of certain analytic and synthetic phytosociological characters. Ecology, 31: 434-455.

Dawkins A.C. (1959). The management of natural tropical high-forest, with special reference to Uganda. Commonwealth forestry, Institute University of Oxford. England. 155p. FAO, 2001 - State of the world's forests. F A O. Rome.

Dongmo Dorisse M. (2002). Etudes floristiques et ethnobotaniques dans un village de la zone forestiere du Cameroun : cas de NKolbibanda.Master thesis, Université de Yaoundé I. 72p.

FAO. (2011). State of the world's forests.FAO, Rome, Italy. 164 p.

Frontier Rougerie G. S. \& D. Pichod-Viale. (1992).Écosystèmes : structure, fonctionnement, évolution. In : Annales de Géographie, t. 101, n565, 1992. pp. 343-344.

Froumsia M., Zapfack L., Mapongmetsem P.M., Nkongmeneck B.A. (2012). Woody species composition, structure and diversity of vegetation of Kalfou Forest Reserve, Cameroon, Journal of Ecology and the Natural Environment 4, pp. 333-343.

Gaoue, O.G. \&Ticktin, T. (2007). Patterns of harvesting foliage and bark from the multipurpose tree Khaya senegalensis in Benin: variation across ecological regions and its impacts on population structure. Biological Conservation, 137:424-436.

Gaoue, O.G. \& Ticktin, T. (2008). Impacts of bark and foliage harvest on Khaya senegalensis (Meliaceae) reproductive performance in Benin. Journal of Applied Ecology, 45:34-40.

IPC C. (2006). Guidelines formational greenhouse gas inventories. Vol.4, Agriculture, Forestry and other land use (AFLOLU). Institute for Global Environmental strategies, Hayama, Japan.45p.

Laminou, M.O., B. Campanella et R. Paul. (2009). Sélection d'espèces ligneuses adaptées à la fixation biologique de dunes au Niger Selection of woody species adapted to biological sand dunes fixation in Niger, Geo-Eco-Trop. 33, pp. 99-106. 
Leblanc M., Malaisse.(1978). Lubumbashi, un écosystème urbain tropical, Centre International de Semiologie, Université National du Zaïre. 178 pp.

Letouzey R. (1985). Carte phytogéographique du Cameroun au 1/500 000è. Domaine sahélien et soudanien. IRA (Herbier National), Yaoundé. Institut de la Carte Internationale de la Végétation, Toulouse, pp.1-26.

Malagnoux, M., E.H. Sene et N. Atzmon.(2007). Les forêts, les arbres et l'eau dans les terres arides : un équilibre précaire, Unasylva 229 58, pp. 24-29.

Mapongmetsem P. M., Etchiké D., Ngassoum M. B. (2016) Conservation et valorisation de la biodiversité dans les agroforêts de la zone périurbaine de la ville Bafia (Région du Centre au Cameroun). Revue Scientifique et Technique Forêt et Environnement du Bassin du Congo,6 :60-69.

Mapongmetsem P.M., Hamawa Y., BayeNiwah C., Froumsia M., Zigro L., Meiga O. S. (2009). Conservation et valorisation de la biodiversité dans les agroforêts de case de la zone SoudanoGuinéenne. In: X. van der Burgt, J. van der Maesenet J.-M. Onana (eds), Systematic and conservation of African plants, Royal Botanic Gardens, Kew pp. 375-384.

Ndjidda.(2001). Structure et dynamiques des espèces ligneuses dans les zones Sud Est du Parc National de Waza. Mémoire du Diplôme d'Ingénieur des Eaux et Forêts, Université de Dschang. 62 p.

Ngom D., Fall T., Sarr O., Diatta S., Akpo E. L. (2013). Ecological Characteristics of the wood stand of the biosphere reserve of the Ferlo(Northern Senegal). Journal of Applied Biosciences, 65:50085023 .

Noiha Noumi V., Zapfack L., Awé Djongmo V., Witanou N., Nyeck B., Ngossomo J.D., Hamadou M.R., Chimi C. D., Tabue Mbobda R. B. (2017a). Floristic structure and sequestration potential of cashew agroecosystems in Africa: A case study from Cameroon. Journal of Sustainable Forestry, 36(3): 277-288.
Noiha Noumi V., Zapfack L., Pelbara P., Awe Djongmo V. \& Tabue Mbobda R. B. (2018a). Afforestation/Reforestation Based on Gmelina Arborea (Verbenaceae) in Tropical Africa: Floristic and Structural Analysis, Carbon Storage and Economic Value (Cameroon). Sustainability in Environment, ISSN 2470-637X (Print) ISSN 2470-6388 (Online), Vol. 3, No. 2, 2018a.

Ouedraogo O., Thiombiano A., Karen Hahn -Hadjali et Guinko S. (2006). Diversité et structure des groupements ligneux du parc national d'Arly (Est du Burkina Faso). Flora et Vegetatio SudanoSambesica, $11: 5-16$.

Piélou E.C. (1969). An introduction to mathematical ecology. New York, USA: Wiley.

Rasatatsihoarana HTF. (2007). Reconnaissances écologiques des aires forestières dans le Menabe sud en vue d'une délimitation de nouvelles aires protégées ; Rapport final Atelier de Joachim (5 septembre 2007).

Roger E. \&Rabarison H. (2000). Contexte biologique de la conservation des forêts à Madagascar. In Etude sur la politique de conservation des ressources forestières à Madagascar. $53 \mathrm{p}$.

Savadogo O. M., Ouattara K., Pare S., Ouedraogo I., Sawadogo-Kaboré S., Barron J., ZombreN. P. (2016). Structure, specific composition and woody vegetation diversity in two contrasted zone in the Sahel of Burkina Faso.Revue éléctronique des sciences de l'environnement, 16(1):1492-8442.

Shannon C.E. \& Weaver W. (1949). The mathematical theory of communication. Urbana, IL, USA: University of Illinois Press.

Thiombiano A., Schmidt M., Kreft H., Guinko S. (2006). Influence du gradient climatique sur la distribution des espèces de Combretaceae au Burkina Faso (Afrique de l'Ouest). Candollea, $61: 189-213$. 